\title{
NEW ANTHRACYCLINES, FEUDOMYCINS, PRODUCED BY THE MUTANT FROM STREPTOMYCES COERULEORUBIDUS ME130-A4
}

\author{
Toshikazu Oki, Yasue Matsuzawa, Kohki Kiyoshima and Akiniro Yoshimoto \\ Central Research Laboratories, Sanraku-Ocean Co., Ltd., Johnan, Fujisawa 251, Japan \\ Hiroshi Naganawa, Tomio Takeuchi and Hamao Umezawa \\ Institute of Microbial Chemistry \\ 14-23 Kamiosaki 3-Chome, Shinagawa-ku, Tokyo 141, Japan
}

(Received for publication April 28, 1981)

\begin{abstract}
Various blocked mutants were isolated from Streptomyces coeruleorubidus ME130-A4 by NTG and UV treatments. Among them, mutant strain $4 \mathrm{~N}-140$ produced new anthracycline feudomycins A and B having new aglycones in which the side chain at C-9 position of daunomycinone was ethyl and acetonyl, respectively. New aglycones feudomycinones C and D having methyl at C-9 and additional hydroxyl group at C-10 of daunomycinone were also isolated from this strain.
\end{abstract}

The isolation of high-yielding variants and the blocked mutants from Streptomyces galilaeus MA144-M1 capable of accumulating new anthracycline metabolites and of glycosidating various anthracyclinones without productivity of pigments was useful for study on the biosynthesis of anthracycline antibiotics and for preparing new products ${ }^{1)}$.

Mutation of $S$. coeruleorubidus ME130-A4, which produces daunomycin-related baumycins, gave unique variants and blocked mutants which varied in the production of new anthracycline compounds, and mutant strain 1U-222 biotransformed $\varepsilon$-pyrromycinone to 1-hydroxydaunomycin-related antibiotics as previously described ${ }^{22}$.

In this paper we describe the isolation of various mutants from S. coeruleorubidus ME130-A4 and the structural elucidation of anthracycline glycosides with new aglycones, feudomycins.

\section{Results}

Isolation of Variants

The original strain ME130-A4 of S. coeruleorubidus produced baumycins A1, A2, B1 and B2 (4'substituted daunomycin), 7-deoxy-13-dihydrodaunomycinone and $\varepsilon$-rhodomycinone. Daunomycin, dihydrodaunomycin, $\mathrm{N}$-acetyl and $\mathrm{N}$-formyldaunomycins, daunomycinone and 13-dihydrodaunomycinone were also accumulated at low levels under the usual fermentation condition.

Mutation of the original strain with NTG or UV induced various variants capable of producing new anthracycline metabolites including non-glycosidic aglycones and pigment-negative mutants. The isolated variants are listed in Table 1, and were characterized according to their metabolic products as follows:

Anthracycline glycoside-producing variants: Strain $1 \mathrm{~N}-364$ was the variant in which major metabolic product was not baumycins but dihydrodaunomycin, while strain $2 \mathrm{~N}-266$ accumulated preferentially daunomycin. Strain $4 \mathrm{~N}-140$ induced from strain $1 \mathrm{~N}-364$ by the successive mutation with NTG 
Table 1. Variants and blocked mutants isolated from Streptomyces coeruleorubidus ME130-A4.

\begin{tabular}{|c|c|c|c|c|}
\hline \multirow{2}{*}{ Group* } & \multirow{2}{*}{ Mutant } & \multicolumn{2}{|c|}{ Mutation } & \multirow{2}{*}{ Major metabolites } \\
\hline & & Original strain & Mutagen & \\
\hline I & $\begin{array}{l}\mathrm{ME} 130-\mathrm{A} 4 \\
1 \mathrm{~N}-364 \\
2 \mathrm{~N}-266 \\
2 \mathrm{~N}-218 \\
4 \mathrm{~N}-140\end{array}$ & $\begin{array}{l}- \\
\mathrm{ME} 130-\mathrm{A} 4 \\
1 \mathrm{~N}-364 \\
\quad " \\
2 \mathrm{~N}-218\end{array}$ & $\begin{array}{c}- \\
\text { NTG } \\
" \\
" \\
"\end{array}$ & $\begin{array}{l}\text { Baumycins A \& B } \\
\text { Dihydrodaunomycin } \\
\text { Daunomycin } \\
\text { Feudomycins A \& B and dihydrodaunomycin } \\
\text { Feudomycins A \& B }\end{array}$ \\
\hline II & $\begin{array}{l}1 \mathrm{U}-85 \\
1 \mathrm{U}-215 \\
1 \mathrm{U}-223 \\
1 \mathrm{~N}-362 \\
1 \mathrm{~N}-367 \\
1 \mathrm{~N}-447 \\
1 \mathrm{~N}-467\end{array}$ & $\begin{array}{c}\text { ME130-A4 } \\
\text { " } \\
\text { " } \\
\text { " } \\
\text { " } \\
\text { " }\end{array}$ & $\begin{array}{c}\text { UV } \\
" \prime \\
" \\
\text { NTG } \\
" \\
" \\
"\end{array}$ & $\begin{array}{l}\varepsilon \text {-Rhodomycinone }(0.82) \\
\text { Yellow aglycone }(0.82) \\
\text { Four violet aglycones }(0.79,0.69,0.46,0.19) \\
\text { Reddish violet aglycone }(0.17) \\
\text { Pink aglycone }(0.30) \\
\text { Five yellow aglycones }(0.86,0.80,0.21,0.15,0.04) \\
\text { Two pink aglycones }(0.78,0.2) ; \\
\text { Two violet aglycones }(0.74,0.23) ; \\
\text { Two gray aglycones }(0.26,0.03)\end{array}$ \\
\hline III & $\begin{array}{l}1 \mathrm{U}-222 \\
1 \mathrm{~N}-372 \\
1 \mathrm{~N}-415\end{array}$ & $\begin{array}{c}\mathrm{ME} 130-\mathrm{A} 4 \\
\prime \prime \\
\prime \prime\end{array}$ & $\begin{array}{l}\text { UV } \\
\text { NTG } \\
\text { " }\end{array}$ & $\begin{array}{c}\text { **Non-productive, but bioconvertable } \\
\text { " } \\
\text { Non-productive and unbioconvertable }\end{array}$ \\
\hline
\end{tabular}

Values in parenthesis show Rf values on TLC using $\mathrm{CHCl}_{3}-\mathrm{MeOH}(10: 1)$.

* Group I: Anthracycline glycoside-producing strains.

Group II: Aglycone-producing strains.

Group III: Anthracyclinone (pigment)-non-producing strains.

** Conversion of exogenous aklavinone to daunomycinone glycosides.

produced new anthracycline feudomycins and related aglycones as described below.

Aglycone-producing variants: In the course of mutation, the blocked mutants capable of producing only $\varepsilon$-rhodomycinone occurred at about $1 \%$ frequency, while daunomycinone- or dihydrodaunomycinone-accumulating mutants were not induced. Six blocked mutants produced violet, gray, pink and yellow unknown aglycone pigments.

Anthracycline-negative mutants: Strain $1 \mathrm{U}-222$ and 1 N-415 were selected by a loss of acetoneextractable red pigment from mycelia, and these strains did not produced any anthracycline pigment in the culture broth. Strain $1 \mathrm{U}-222$ possessed the ability to produce the parent glycosides when aklavinone or $\varepsilon$-rhodomycinone was exogenously added to the culture ${ }^{3)}$, whereas strain $1 \mathrm{~N}-415$ lacked both activities of glycosidation and pigment-formation.

Feudomycins A and B Produced by a Mutant Strain 4N-140

Feudomycins A (II) and B (III) were red crystalline powders having molecular formulae $\mathrm{C}_{27} \mathrm{H}_{31^{-}}$ $\mathrm{NO}_{9}$ and $\mathrm{C}_{28} \mathrm{H}_{31} \mathrm{NO}_{10}$, respectively. UV/Visible spectra of II and III were quite similar to that of daunomycin (I). The IR spectra of II and III were also very similar to that of I, excepting that the acetyl carbonyl peak $\left(1700 \mathrm{~cm}^{-1}\right)$ observed in I and III was missing in II. Their CMR spectra indicated that II had the same 27 carbons as I and III had 28 (Fig. 1), and that II possessed ethyl carbons ( $\delta 7.4$ and 35.4) instead of acetyl carbons ( $\delta 24.8$ and 212.0) in I. III had one more methylene carbon ( $\delta 54.1)$ than I. The peaks assigned for the sugar moiety were same throughout. 
Fig. 1. CMR spectra of daunomycin (I), feudomycin A (II) and feudomycin B (III).
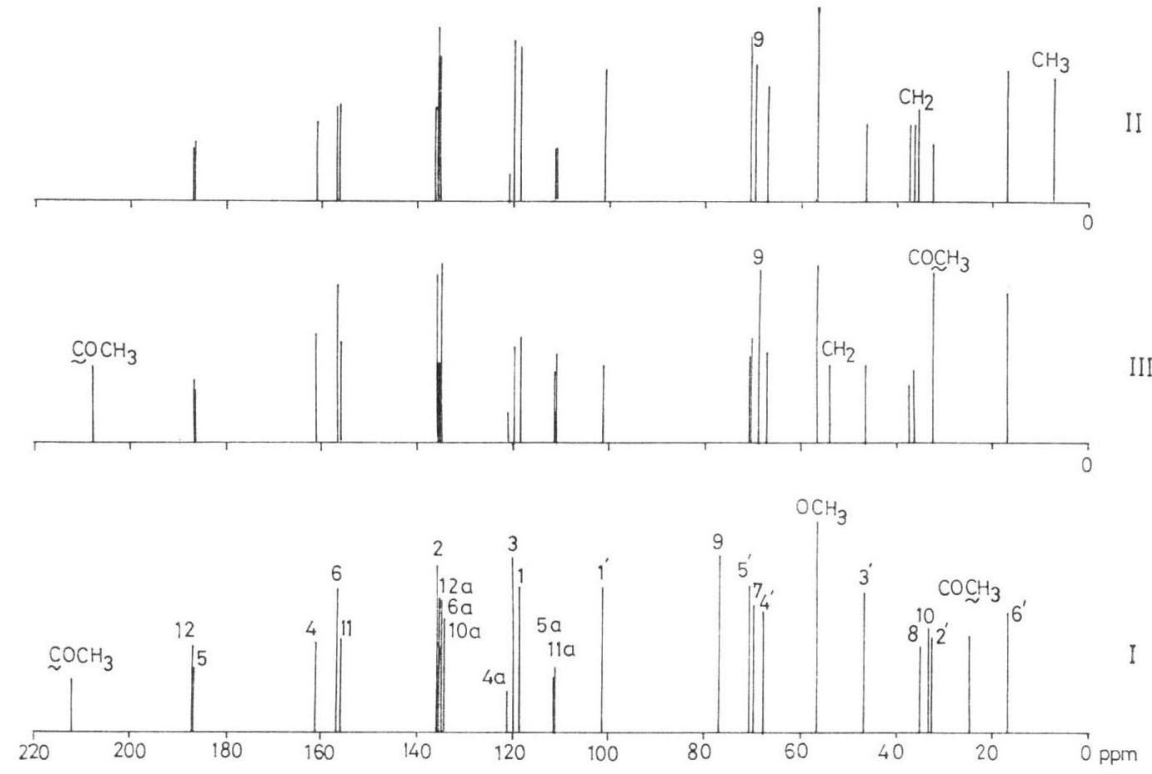

Acid hydrolysis of II and III with $0.1 \mathrm{~N} \mathrm{HCl}$ gave red aglycones, named as feudomycinones A and B respectively. The sugar moiety obtained from the aqueous layer of the acid hydrolysates was determined as daunosamine by a direct comparison with the authentic sample on TLC.

Feudomycinone A (IV) melted at $201 \sim 206^{\circ} \mathrm{C}$ and had a molecular formula $\mathrm{C}_{21} \mathrm{H}_{20} \mathrm{O}_{7}$ as established by elemental analysis and MS spectrum. The PMR spectrum of IV showed the presence of ethyl protons ( $\delta 1.08$ and $1.6 \sim 1.95$ ) instead of acetyl protons ( $\delta 2.44)$ in daunomycinone (IX), and its IR spectrum also indicated absence of the acetyl carbonyl group. In the CMR spectrum of $\mathbf{I V}$, the shift of carbon at C-9 to higher field and the presence of additional ethyl carbons ( $\delta 7.4$ and 35.3) were observed in comparison with IX. These data supported IV as 13-deoxodaunomycinone and II was thus identical to 13-deoxodaunomycin, which had been chemically synthesized from $\varepsilon$-rhodomycinone ${ }^{4)}$.

Feudomycinone B (V) from III had a molecular formula of $\mathrm{C}_{22} \mathrm{H}_{20} \mathrm{O}_{8}$ and melting point of 184 $189^{\circ} \mathrm{C}$. IR and PMR spectra revealed the presence of an acetyl group in V. In the PMR spectrum of $\mathbf{V}$, the acetyl protons were shifted to higher field $(\delta 2.30)$ than those of IX $(\delta 2.44)$ and the broad singlet peak at $\delta 2.84$ was assigned to the isolated methylene protons. Moreover, the off-resonance CMR spectrum of $\mathbf{V}$ showed the triplet peak at $\delta 53.6$, to be assigned to the methylene carbon, which was shifted to low field. On the contrary, the carbon at C-9 ( $\delta$ 69.0) and the acetyl carbonyl ( $\delta$ 207.9) were shifted to higher field than those of IX ( $\delta 76.9$ and 212.0). These spectral data suggested the presence of one methylene group between the carbon at C-9 and the acetyl ketonic carbon. Further structural confirmation of $\mathbf{V}$ was provided by the spectral analysis of VIII which was obtained by hydrogenation of $\mathbf{V}$ with sodium borohydride. VIII had a molecular weight of 414 by mass spectral analysis, which showed that two hydrogen atoms were introduced into $\mathbf{V}$. The IR spectrum showed the absence of the carbonyl absorption peak in VIII. The PMR spectrum of VIII indicated the loss of both peaks of acetyl and methylene in the low field and the appearance of two peaks splitting as doublets at $\delta 1.15(3 \mathrm{H}, J=6.5)$ and $\delta 1.66(2 \mathrm{H}, J=6.2)$ which were assigned as methyl protons at $\mathrm{C}-15$ 
Fig. 2. Structure of daunomycin and feudomycins.

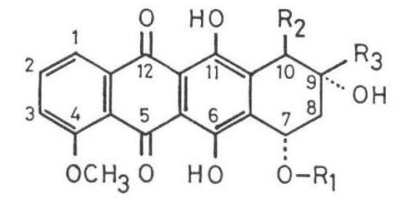

\begin{tabular}{ll|ccl}
\hline & & $\mathrm{R}_{1}$ & $\mathrm{R}_{2}$ & \\
\hline I & (Daunomycin) & $\mathrm{R}_{3}$ \\
II & (Feudomycin A) & $\mathrm{H}$ & $\mathrm{COCH}_{3}$ \\
III & (Feudomycin B) & $\mathrm{H}$ & $\mathrm{CH}_{2} \mathrm{CH}_{3}$ \\
IV & (Feudomycinone a=13-deoxodaunomycinone) & $\mathrm{H}$ & $\mathrm{H}$ & $\mathrm{CH}_{2} \mathrm{CH}_{3}$ \\
V & (Feudomycinone B) & $\mathrm{H}$ & $\mathrm{H}$ & $\mathrm{CH}_{2} \mathrm{COCH}_{3}$ \\
VI & (Feudomycinone C) & $\mathrm{H}$ & $\mathrm{H}$ & $\mathrm{CH}_{3}$ \\
VII (Feudomycinone D) & $\mathrm{H}$ & $\mathrm{OH}$ & $\mathrm{CH}_{3}$ \\
VIII (Dihydrofeudomycinone B) & $\mathrm{H}$ & $\mathrm{H}$ & $\mathrm{CH}_{2} \mathrm{CHOHCH}_{3}$ \\
IX (Daunomycinone) & $\mathrm{H}$ & $\mathrm{H}$ & $\mathrm{COCH}_{3}$ \\
\hline
\end{tabular}

and methylene protons at $\mathrm{C}-13$, respectively. $\quad \mathbf{V}$ is proposed as a new aglycone (feudomycinone $\mathrm{B}$ ) in which the acetyl at $\mathrm{C}-9$ of $\mathbf{I X}$ is replaced by acetonyl, and thus III is 9-acetonyldaunomycin (feudomycin B), as shown in Fig. 2.

New Aglycones, Feudomycinones C and D

Feudomycinones $\mathrm{C}$ (VI) and D (VII) were minor components and isolated from the acid hydrolysate of crude extract from the cultured broth of a mutant strain $4 \mathrm{~N}-140$ culture.

The melting points of VI and VII were $218 \sim 219^{\circ} \mathrm{C}$ and $132 \sim 135^{\circ} \mathrm{C}$, respectively. The molecular formulae of VI and VII were $\mathrm{C}_{20} \mathrm{H}_{18} \mathrm{O}_{7}$ and $\mathrm{C}_{20} \mathrm{H}_{18} \mathrm{O}_{8}$, respectively. The absence of the acetyl group at C-9 in both aglycones was observed in the IR and PMR spectra. PMR spectrum indicated that the isolated methyl group ( $\delta 1.47$ ) with a singlet peak was present in VI. Other peaks were superimposable on those, except for the acetyl protons, of IX. Thus, VI was identified as 9-methyldaunomycinone (feudomycinone C). On the other hand, the PMR spectrum of VII also showed isolated methyl protons with a singlet peak at $\delta 1.30$. The proton at $\mathrm{C}-10$ appeared as a doublet peak at lower field $(\delta 4.50)$ than that of IX $(\delta 2.5 \sim 3.4)$. This proton was coupled with the hydroxyl group splitting as a doublet at $\delta 5.48$ with a coupling constant of $6.2 \mathrm{~Hz}$ which was exchanged with $\mathrm{D}_{2} \mathrm{O}$. From the results, VII was identified as 9-methyl-10-hydroxydaunomycinone (feudomycinone D) as shown in Fig. 2.

\section{Discussion}

S. coeruleorubidus ME130-A4 produces baumycins in which daunomycin was substituted at C-4' of daunosamine with an acetal residue. It is of great interest that baumycins and 4-hydroxybaumycins were also accumulated in the culture of $S$. peucetius known as an adriamycin producer (unpublished data) and Actinomadura strain D326 ${ }^{5)}$. Blumauerova et al. have reported the isolation of blocked mutants from $S$. coeruleorubidus which accumulated non-glycosidated aglycones such as $\varepsilon$-rhodomycinone or aklavinone ${ }^{\theta)}$; we isolated $\varepsilon$-rhodomycinone-producers and other unidentified aglycone producers from S. coeruleorubidus ME130-A4. We demonstrated that $\varepsilon$-rhodomycinone is a precursor aglycone in the biosynthesis of daunomycinone ${ }^{3)}$, and proposed that daunomycin is biosynthesized via 
glycosidation of $\varepsilon$-rhodomycinone followed by 10-decarbomethoxylation and further $\beta$-oxidation of ethyl at C-9. Feudomycin A (13-deoxodaunomycin) was found to be an intermediate in the daunomycin biosynthesis as deduced from the proposed biosynthetic pathway ${ }^{7)}$. It seems likely that other daunomycinone-related aglycones with a side chain of methyl or acetonyl at C-9 position arise from irregularity in the formation of the polyketide. It has been reported that daunomycinone was basically formed by the condensation of nine units of acetate and one propionate ${ }^{8)}$. Thus, it is deduced that the above aglycones were built from ten units of acetate in the methyl analog and 11 acetate units or nine units of acetate and one butylate or one acetoacetate unit in the acetonyl analog, as shown in Fig. 3 .

The production of new aglycones having methyl and acetonyl group at C-9 position of aklavinone, named as auramycinone and sulfurmycinone, respectively, was recently reported with $S$. galilaeus by FuJWARA et al. ${ }^{9)}$. We also recently found an additional 13-methylaklavinone in the aclacinomycin broth as a minor component ${ }^{10)}$. This may be formed from nine units of acetate and one isobutylate. These results showed that the starter carbon unit in the formation of polyketide leading to anthracyclinone is usually propionate, but variable under cultural conditions where the propionate level was suppressed by any reason, so that new anthracyclinone aglycones with different side chains at C-9 position could be produced.

\section{Experimental}

Microorganisms

The original strain ME130-A4 and mutant strains of Streptomyces coeruleorubidus were maintained on YS agar $(0.3 \%$ yeast extract, $1 \%$ soluble starch, $1.5 \%$ agar, $\mathrm{pH} 7.2)$. Anthracycline compounds produced by strain ME130-A4 were previously described ${ }^{7,11)}$.

\section{Mutation}

Spore cells $\left(5 \times 10^{8}\right.$ cells $\left./ \mathrm{ml}\right)$ of $S$. coeruleorubidus ME130-A4 from the culture grown for one week on YS agar were exposed to $1 \mathrm{mg} / \mathrm{ml}$ of $N$-methyl- $N^{\prime}$-nitro- $N$-nitrosoguanidine (NTG) in $0.2 \mathrm{M}$ tris- $\mathrm{HCl}(\mathrm{pH} 8.5)$ with shaking at $28^{\circ} \mathrm{C}$ in the dark, or the spore suspension $\left(5 \times 10^{9}\right.$ cells $/ 10 \mathrm{ml}$ of saline $)$ in a Petri dish were irradiated by ultraviolet light (UV). Both treatments were performed to give about $5 \sim 0.5 \%$ survivals. The treated spore cells were plated on YS agar after dilution with saline and incubated for 5 days at $28^{\circ} \mathrm{C}$. About $200 \sim 500$ colonies were taken on YS agar slant and tested for the production of anthracycline compounds as described below.

\section{Analyticals}

Thin-layer (TLC) and preparative layer (PLC) chromatographies were carried out on silica gel $60 \mathrm{~F}_{254}$ and $60 \mathrm{PF}_{254}$ plates (E. Merck \& Co.) using the following solvent systems: $\mathrm{S} 1 ; \mathrm{CHCl}_{3}-\mathrm{MeOH}-$ ammonia water (90: 10: 0.2, v/v/v), S2; $\mathrm{CHCl}_{3}-\mathrm{MeOH}$ - acetic acid (80: 20: 4, v/v/v), S3; $\mathrm{CHCl}_{3}$ $\mathrm{MeOH}(40: 1, \mathrm{v} / \mathrm{v}), \mathrm{S} 4 ; \mathrm{CHCl}_{3}-\mathrm{MeOH}(20: 1, \mathrm{v} / \mathrm{v}), \mathrm{S} 5$; benzene - acetic acid - formic acid (100: 30: 1, 
$\mathrm{v} / \mathrm{v} / \mathrm{v})$ and $\mathrm{S} 6 ; n-\mathrm{BuOH}$ - acetic acid - water $(4: 1: 1, \mathrm{v} / \mathrm{v} / \mathrm{v})$. The extraction of anthracycline pigment from the removed silica gel was done by a solvent mixture of $\mathrm{CHCl}_{3}-\mathrm{MeOH}$ - ammonia water (100: 15: $0.2, \mathrm{v} / \mathrm{v} / \mathrm{v}$ ) (S7). Wakogel C-200 (silica gel, $74 \sim 149 \mu$, Wako Junyaku) and Sephadex LH-20 (Pharmacia Fine Chemicals) were employed for the column chromatography.

The detection of sugars was done by spraying the TLC plate with a mixture of $5 \% p$-anisaldehyde and $5 \%$ sulfuric acid in ethanol and heating at $90^{\circ} \mathrm{C}$ for color development.

Detection of Anthracycline Compounds

Cultures on YS agar were inoculated in YS medium ( $4 \mathrm{ml} /$ test tube), incubated on a reciprocal shaker at $28^{\circ} \mathrm{C}$ for 2 days, and added to a $250-\mathrm{ml}$ Erlenmeyer flask containing $30 \mathrm{ml}$ of the fermentation medium as described in a previous paper ${ }^{7}$. The fermentation took place by cultivation at $28^{\circ} \mathrm{C}$ for 3 days on a rotary shaker $(220 \mathrm{rpm})$. Five $\mathrm{ml}$ of the culture broth was sampled and centrifuged, and the pigments in the mycelial pellet were extracted with $5 \mathrm{ml}$ of acetone. The acetone extract was concentrated in vacuo and re-extracted with $2 \mathrm{ml}$ of chloroform. The extract was separated into two parts and evaporated to dryness. The pigment residues of one part were hydrolyzed in $1 \mathrm{ml}$ of $0.1 \mathrm{~N} \mathrm{HCl}$ at $85^{\circ} \mathrm{C}$ for 30 minutes to obtain aglycones and extracted with $1 \mathrm{ml}$ of chloroform. Pigments in the hydrolysate were chromatographed on a silica gel plate using solvent system of $\mathrm{CHCl}_{3}-\mathrm{MeOH}$ (10: 1 or 20: 1) and compared with authentic sample on TLC.

\section{Fermentation of Strain $4 \mathrm{~N}-140$}

The seed culture of strain $4 \mathrm{~N}-140$ was prepared by cultivation at $28^{\circ} \mathrm{C}$ for 2 days on a rotary shaker in a $500 \mathrm{ml}$ Erlenmeyer flask containing $100 \mathrm{ml}$ of the following medium: $1.5 \%$ soluble starch, $0.1 \%$ yeast extract, $0.1 \% \mathrm{~K}_{2} \mathrm{HPO}_{4}, 0.1 \% \mathrm{MgSO}_{4} \cdot 7 \mathrm{H}_{2} \mathrm{O}$ and $0.3 \% \mathrm{NaCl}, \mathrm{pH} 7.4$, one $\mathrm{ml}$ of which was added to a $500-\mathrm{ml}$ Erlenmeyer flask containing $50 \mathrm{ml}$ of the fermentation medium as described in a previous paper ${ }^{11)}$. Cultivation was performed for 5 days at $28^{\circ} \mathrm{C}$ on a rotary shaker $(220 \mathrm{rpm})$. The culture broth (20 liters) thus obtained was centrifuged and the pigments were extracted from the mycelia with acetone and the supernatant fluid with chloroform, and the combined extract was evaporated to oily crude pigments.

Isolation of Feudomycins A and B

The crude pigment extract from strain $4 \mathrm{~N}-140$ was dissolved in methanol and the insoluble material was centrifuged. The supernatant was subjected to a Sephadex LH-20 column $(\phi 5 \times 45 \mathrm{~cm})$ and eluted with a $\mathrm{CHCl}_{3}-\mathrm{MeOH}$ - ammonia water $(125: 250: 1, \mathrm{v} / \mathrm{v} / \mathrm{v})$ mixture. The eluate containing anthracycline glycosides was pooled and concentrated in vacuo to dryness. The residue was dissolved in $200 \mathrm{ml}$ of toluene and extracted three times with $200 \mathrm{ml}$ of $0.1 \mathrm{M}$ acetate buffer $(\mathrm{pH} \mathrm{3.0)}$. The aqueous layer was extracted twice with $200 \mathrm{ml}$ of $\mathrm{CHCl}_{3}$ after adjusting to $\mathrm{pH} 7$ with saturated $\mathrm{NaHCO}_{3}$ solution. The extract was dried over anhydrous $\mathrm{Na}_{2} \mathrm{SO}_{4}$, filtered and evaporated to dryness. The residue (425 mg) was chromatographed on PLC using the solvent system S1. Three major red bands appeared at $\mathrm{Rf}$ values of 0.15 (feudomycin A), 0.13 (feudomycin B), and 0.02 (dihydrodaunomycin). The regions of these bands were scratched and extracted with solvent S7. Further purification was done by rechromatography on PLC using solvent S2. Each component thus obtained was dissolved in $20 \mathrm{ml}$ of $0.1 \mathrm{M}$ acetate buffer $(\mathrm{pH} 3.0)$ and the aqueous solution was washed with $10 \mathrm{ml}$ of toluene and reextracted twice with $20 \mathrm{ml}$ of $\mathrm{CHCl}_{3}$ after adjusting to $\mathrm{pH} 7.0$ with $10 \% \mathrm{NaHCO}_{3}$ solution. The $\mathrm{CHCl}_{3}$ layer was dried over anhydrous $\mathrm{Na}_{2} \mathrm{SO}_{4}$ and concentrated to a small volume and the pure pigments were obtained as red powder by precipitating with excess $n$-hexane; $57.9 \mathrm{mg}$ of feudomycin $\mathrm{A} ; 31.8 \mathrm{mg}$ of feudomycin B; $52 \mathrm{mg}$ of dihydrodaunomycin.

Feudomycin A: Red amorphous powder, m.p. $158 \sim 163^{\circ} \mathrm{C},[\alpha]_{\mathrm{D}}^{23}+243^{\circ}(c 0.044, \mathrm{MeOH}), \lambda_{\max }^{\mathrm{MeOH}} \mathrm{nm}$ $\left(\mathrm{E}_{1 \mathrm{~cm}}^{1 \%}\right): 235$ (688), 253 (510), $290(170), 475(227), 497$ (235), $530(135), \nu_{\max }^{\mathrm{KBr}} \mathrm{cm}^{-1}: 1620,1580,1120$, PMR $\left(\mathrm{CDCl}_{3}\right) \delta$ in ppm: $1.07(3 \mathrm{H}, \mathrm{t}, J=7.5, \mathrm{H}-14), 1.34\left(3 \mathrm{H}, \mathrm{d}, J=6.5, \mathrm{H}-6^{\prime}\right), 1.6 \sim 1.8(4 \mathrm{H}, \mathrm{m}, \mathrm{H}-13$ and $2^{\prime}$ ), $1.7 \sim 2.4(2 \mathrm{H}, \mathrm{m}, \mathrm{H}-8), 2.4 \sim 3.3\left(3 \mathrm{H}, \mathrm{m}, \mathrm{H}-10\right.$ and $\left.3^{\prime}\right), 3.47\left(1 \mathrm{H}, \mathrm{bs}, \mathrm{H}-4^{\prime}\right), 4.04$ (3H, s, OMe), $4.0 \sim 4.2\left(1 \mathrm{H}, \mathrm{q}, J=6.5, \mathrm{H}-5^{\prime}\right), 5.16(1 \mathrm{H}, \mathrm{bs}, \mathrm{H}-7), 5.46\left(1 \mathrm{H}, \mathrm{bs}, \mathrm{H}-1^{\prime}\right), 7.33(1 \mathrm{H}, \mathrm{dd}, J=1.5$ and $8, \mathrm{H}-3)$, $7.72(1 \mathrm{H}, \mathrm{t}, J=8.0, \mathrm{H}-2), 7.92(1 \mathrm{H}, \mathrm{dd}, J=1.5$ and 8.0, H-1). (Found: C 62.41, H 5.95, N 2.77, Calcd. for $\mathrm{C}_{27} \mathrm{H}_{31} \mathrm{NO}_{9}: \mathrm{C} 63.15, \mathrm{H} 6.08, \mathrm{~N} 2.73 \%$ ). 
Feudomycin B: Red amorphous powder, m.p. $148 \sim 150^{\circ} \mathrm{C},[\alpha]_{\mathrm{D}}^{23}+146^{\circ}(c 0.04, \mathrm{MeOH}), \lambda_{\max }^{\mathrm{MeOH}} \mathrm{nm}$ $\left(\mathrm{E}_{1 \mathrm{~cm}}^{1 \%}\right): 235$ (631), 253 (461), $290(170), 475(214), 498(224), 532(130), \nu_{\max }^{\mathrm{KBr}} \mathrm{cm}^{-1}: 1700,1615,1580$, 1010, PMR $\left(\mathrm{CDCl}_{3}\right) \delta$ in ppm: $1.36\left(3 \mathrm{H}, \mathrm{d}, J=6.5, \mathrm{H}-6^{\prime}\right), 1.65 \sim 1.8\left(2 \mathrm{H}, \mathrm{m}, \mathrm{H}-2^{\prime}\right), 1.85 \sim 2.75(2 \mathrm{H}, \mathrm{m}$, H-8), 2.28 ( $3 \mathrm{H}, \mathrm{s}, \mathrm{Ac}), 2.5 \sim 3.5(2 \mathrm{H}, \mathrm{m}, \mathrm{H}-10), 2.85(2 \mathrm{H}, \mathrm{bs}, \mathrm{H}-13), 3.0 \sim 3.2\left(1 \mathrm{H}, \mathrm{m}, \mathrm{H}-3^{\prime}\right), 3.5(1 \mathrm{H}$, bs, H-4') $4.02(3 \mathrm{H}, \mathrm{s}, \mathrm{OMe}), 3.95 \sim 4.2\left(1 \mathrm{H}, \mathrm{q}, J=6.5, \mathrm{H}-5^{\prime}\right), 5.10(1 \mathrm{H}, \mathrm{bs}, \mathrm{H}-7), 5.46\left(1 \mathrm{H}, \mathrm{bs}, \mathrm{H}-1^{\prime}\right)$, $7.31(1 \mathrm{H}$, dd, $J=1.5$ and 8.0, H-3), $7.7(1 \mathrm{H}, \mathrm{t}, J=8.0, \mathrm{H}-2), 7.94(1 \mathrm{H}, \mathrm{dd}, J=1.5$ and $8.0, \mathrm{H}-1)$. (Found: C 61.98, H 5.77, N 2.34, Calcd. for $\mathrm{C}_{28} \mathrm{H}_{31} \mathrm{NO}_{10}$ : C 62.10, H 5.77, N 2.59\%).

\section{Isolation of Feudomycinones $\mathrm{A}, \mathrm{B}, \mathrm{C}$ and $\mathrm{D}$}

The crude pigment extract from 20 liters of cultured broth of strain $4 \mathrm{~N}-140$ was dissolved in $30 \mathrm{ml}$ of acetone and added $200 \mathrm{ml}$ of $0.3 \mathrm{~N} \mathrm{HCl}$. The mixture was heated at $85^{\circ} \mathrm{C}$ for 60 minutes, extracted twice with $200 \mathrm{ml}$ of $\mathrm{CHCl}_{3}$ and evaporated in vacuo to dryness. The oily residue was chromatographed on a silica gel column $(\phi 4 \times 20 \mathrm{~cm})$ using $\mathrm{CHCl}_{3}-\mathrm{MeOH}(100: 2$ and 100: 5). Feudomycinone A was eluted with concomitant daunomycinone. Further purification was done by PLC using solvent S5 and feudomycinone A was crystallized from acetone to yield $48.3 \mathrm{mg}$. The fractions containing feudomycinone B, C or D were respectively purified by further twice PLC in which solvent S5 and subsequent $\mathrm{S} 4$ were used. The pure aglycones were crystallized from acetone. Their yields were; feudomycinone B, $26.7 \mathrm{mg}$; feudomycinone C, $11.9 \mathrm{mg}$; feudomycinone $\mathrm{D}, 15.8 \mathrm{mg}$.

Feudomycinone A: Red crystals, m.p. $201 \sim 206^{\circ} \mathrm{C},[\alpha]_{\mathrm{D}}^{23}+181^{\circ}(c 0.02, \mathrm{MeOH}), \lambda_{\max }^{\mathrm{MeOH}} \mathrm{nm}$ $\left(\mathrm{E}_{1 \mathrm{~cm}}^{1 \%}\right): 235$ (920), 253 (706), 290 (220), 475 (312), $497(325), 530(183), \nu_{\max }^{\mathrm{KBr}} \mathrm{cm}^{-1}: 1620,1580, \mathrm{PMR}$ $\left(\mathrm{CDCl}_{3}\right) \delta$ in ppm: $1.08(3 \mathrm{H}, \mathrm{t}, J=7.5, \mathrm{H}-14), 1.6 \sim 1.95(4 \mathrm{H}, \mathrm{m}, \mathrm{H}-13$ and 8$), 2.25 \sim 3.25(2 \mathrm{H}, \mathrm{m}, \mathrm{H}-10)$, $3.47\left(1 \mathrm{H}, \mathrm{s}, \mathrm{OH}-9\right.$ exchanged with $\left.\mathrm{D}_{2} \mathrm{O}\right), 3.7\left(1 \mathrm{H}, \mathrm{d}, J=5.5, \mathrm{OH}-7\right.$ exchanged with $\left.\mathrm{D}_{2} \mathrm{O}\right), 4.06(3 \mathrm{H}, \mathrm{s}$, OMe), $5.26(1 \mathrm{H}, \mathrm{bs}, \mathrm{H}-7), 7.36(1 \mathrm{H}, \mathrm{dd}, \mathrm{H}-3), 7.75(1 \mathrm{H}, \mathrm{t}, \mathrm{H}-2), 8.00(1 \mathrm{H}, \mathrm{dd}, \mathrm{H}-1), 13.24$ and 13.90 $\left(2 \mathrm{H}, \mathrm{s} \times 2\right.$, phenolic $\mathrm{OH}$ exchanged with $\left.\mathrm{D}_{2} \mathrm{O}\right)$, MS: $m / z 384\left(\mathrm{M}^{+}\right)$. (Found: $\mathrm{C} 65.55, \mathrm{H} \mathrm{5.27}$, Calcd. for $\mathrm{C}_{21} \mathrm{H}_{20} \mathrm{O}_{7}$ : C $65.62, \mathrm{H} 5.24 \%$ ).

Feudomycinone B: Red crystals, m.p. $184 \sim 189^{\circ} \mathrm{C},[\alpha]_{\mathrm{D}}^{23}+158^{\circ}(c 0.02, \mathrm{MeOH}), \lambda_{\max }^{\mathrm{MeOH}} \mathrm{nm}\left(\mathrm{E}_{1 \mathrm{~cm}}^{1 \% \%}\right)$ : 236 (922), 253 (676), 292 (214), 473 (308), 497 (317), 532 (176), $\nu_{\max }^{\mathrm{KBr}} \mathrm{cm}^{-1}: 1700,1610,1580$, PMR $\left(\mathrm{CDCl}_{3}\right) \delta$ in ppm: $1.85 \sim 2.35(2 \mathrm{H}, \mathrm{m}, \mathrm{H}-8), 2.30(3 \mathrm{H}, \mathrm{s}, \mathrm{Ac}), 2.84(2 \mathrm{H}, \mathrm{bs}, \mathrm{H}-13), 2.5 \sim 3.45(2 \mathrm{H}, \mathrm{m}$, $\mathrm{H}-10), 3.97\left(1 \mathrm{H}, \mathrm{d}, J=6.0\right.$, OH-7 exchanged with $\left.\mathrm{D}_{2} \mathrm{O}\right), 4.06(3 \mathrm{H}, \mathrm{s}, \mathrm{OMe}), 4.46(1 \mathrm{H}, \mathrm{s}, \mathrm{OH}-9$, exchanged with $\left.\mathrm{D}_{2} \mathrm{O}\right), 5.16(1 \mathrm{H}, \mathrm{bs}, \mathrm{H}-7), 7.36(1 \mathrm{H}, \mathrm{dd}, \mathrm{H}-3), 7.75(1 \mathrm{H}, \mathrm{t}, \mathrm{H}-2), 7.98(1 \mathrm{H}, \mathrm{dd}, \mathrm{H}-1), 13.24$ and $13.91\left(2 \mathrm{H}, \mathrm{s} \times 2\right.$, phenolic $\mathrm{OH}$ exchanged with $\mathrm{D}_{2} \mathrm{O}$ ). MS: $\mathrm{m} / z$ 412( $\mathrm{M}^{+}$) (Found: $\mathrm{C} 63.60, \mathrm{H} 5.05$, Calcd. for $\mathrm{C}_{22} \mathrm{H}_{20} \mathrm{O}_{8}$ : C $64.08, \mathrm{H} 4.89 \%$ ).

Feudomycinone C: Red crystals, m.p. $218 \sim 219^{\circ} \mathrm{C},[\alpha]_{\mathrm{D}}^{23}+160^{\circ}(c 0.02, \mathrm{MeOH}), \lambda_{\max }^{\mathrm{MeOH}} \mathrm{nm}$ $\left(\mathrm{E}_{1 \mathrm{c} m}^{1 \% 6}\right): 235$ (902), $252(688), 290(215), 472(305), 495(317), 530(176), \nu_{\max }^{\mathrm{KBr}} \mathrm{cm}^{-1}: 1610,1580$, PMR $\left(\mathrm{CDCl}_{3}-\mathrm{CD}_{3} \mathrm{OD}, 5: 1\right) \delta$ in ppm: $1.47(3 \mathrm{H}, \mathrm{s}, \mathrm{H}-13), 1.8 \sim 2.5(2 \mathrm{H}, \mathrm{m}, \mathrm{H}-8), 2.4 \sim 3.32(2 \mathrm{H}, \mathrm{m}, \mathrm{H}-10)$, $4.06(3 \mathrm{H}, \mathrm{s}, \mathrm{OMe}), 5.21(1 \mathrm{H}, \mathrm{bs}, \mathrm{H}-7), 7.40(1 \mathrm{H}, \mathrm{dd}, \mathrm{H}-3), 7.75(1 \mathrm{H}, \mathrm{t}, \mathrm{H}-2), 7.96(1 \mathrm{H}, \mathrm{dd}, \mathrm{H}-1), 13.28$ and $13.92\left(2 \mathrm{H}, \mathrm{s} \times 2\right.$, phenolic $\mathrm{OH}$ exchanged with $\left.\mathrm{D}_{2} \mathrm{O}\right)$. $\mathrm{MS}: \mathrm{m} / z 370\left(\mathrm{M}^{+}\right)$. (Found: $\mathrm{C} 64.26$, $\mathrm{H} 4.89$, Calcd. for $\mathrm{C}_{20} \mathrm{H}_{18} \mathrm{O}_{7}: \mathrm{C} 64.86, \mathrm{H} 4.90 \%$ ).

Feudomycinone D: Red crystals, m.p. $132 \sim 135^{\circ} \mathrm{C}, \lambda_{\max }^{\mathrm{MeOH}} \mathrm{nm}\left(\mathrm{E}_{1 \mathrm{~cm}}^{1 \%}\right): 235$ (403), 252 (315), 293 (74), 502 (121), 537 (143), $579(116), \nu_{\max }^{\mathrm{KBr}} \mathrm{cm}^{-1}: 1615,1585$, PMR (DMSO- $\left.d_{6}\right) \delta$ in ppm: $1.30(3 \mathrm{H}, \mathrm{s}, \mathrm{H}-13)$, $1.7 \sim 2.2$ ( $2 \mathrm{H}, \mathrm{m}, \mathrm{H}-8), 3.90(3 \mathrm{H}, \mathrm{s}, \mathrm{OMe}), 4.50(1 \mathrm{H}, \mathrm{d}, J=6.2, \mathrm{H}-10), 4.75 \sim 5.10$ ( $2 \mathrm{H}, \mathrm{m}, \mathrm{H}-7$ overlapped with $\mathrm{OH}-7$ exchanged with $\left.\mathrm{D}_{2} \mathrm{O}\right), 5.20\left(1 \mathrm{H}, \mathrm{s}, \mathrm{OH}-9\right.$ exchanged with $\left.\mathrm{D}_{2} \mathrm{O}\right), 5.48(1 \mathrm{H}, \mathrm{d}, J=6.2, \mathrm{OH}-10$ exchanged with $\left.\mathrm{D}_{2} \mathrm{O}\right), 7.5(1 \mathrm{H}$, dd, $\mathrm{H}-3), 7.8 \sim(2 \mathrm{H}, \mathrm{m}, \mathrm{H}-1$ and 2$), 12.43$ and $12.95(2 \mathrm{H}, \mathrm{s} \times 2$, phenolic $\mathrm{OH}$ exchanged with $\mathrm{D}_{2} \mathrm{O}$ ).

\section{Reduction of Feudomycinone B}

Sodium borohydride $(5 \mathrm{mg})$ was added to a solution of feudomycinone B $(25 \mathrm{mg})$ in a mixture of $\mathrm{CHCl}_{3}(25 \mathrm{ml})$ and ethanol $(2.5 \mathrm{ml})$, which was stirred at room temperature for 30 minutes. $5 \times 10^{-3} \mathrm{M}$ EDTA solution $(20 \mathrm{ml})$ and $\mathrm{CHCl}_{3}(10 \mathrm{ml})$ were then added and the mixture was vigorously shaken. The chloroform layer was washed with distilled water, dried over anhydrous $\mathrm{Na}_{2} \mathrm{SO}_{4}$ and evaporated in vacuo to dryness $(18 \mathrm{mg})$. The residue was purified by PLC with solvent S4 and crystallized from acetone to yield $5 \mathrm{mg}$ of 14 -dihydrofeudomycinone B: Red needle crystals, m.p. $188 \sim 193^{\circ} \mathrm{C},[\alpha]_{\mathrm{D}}^{23}+183^{\circ}$ 
(c 0.02, MeOH), $\lambda_{\max }^{\mathrm{MeOH}} \mathrm{nm}\left(\mathrm{E}_{1 \mathrm{~cm}}^{1 \%}\right): 236(850), 250(685), 290(197), 475$ (281), 497 (290), 530 (165), PMR (DMSO- $\left.d_{b}\right) \delta$ in ppm: $1.15(3 \mathrm{H}, \mathrm{d}, J=6.5, \mathrm{H}-15), 1.66(2 \mathrm{H}, J=6.5, \mathrm{H}-13), 1.8 \sim 2.4(2 \mathrm{H}, \mathrm{m}, \mathrm{H}-8)$, $2.6 \sim 3.2$ (2H, m, H-10), 4.02 (3H, s, OMe), $4.7 \sim(1 \mathrm{H}, \mathrm{m}, \mathrm{H}-14), 5.02 \sim(1 \mathrm{H}, \mathrm{m}, \mathrm{H}-7), 7.68$ (1H, dd, H-3), $7.93(2 \mathrm{H}, \mathrm{m}, \mathrm{H}-1$ and 2$), \mathrm{MS}: m / z 414\left(\mathrm{M}^{+}\right)$.

\section{References}

1) Oki, T.; A. Yoshimoto, Y. Matsuzawa, T. Takeuchi \& H. Umezawa: Biosynthesis of anthracycline antibiotics by Streptomyces galilaeus. I. Glycosidation of various anthracyclinones by an aclacinomycinnegative mutant and biosynthesis of aclacinomycins from aklavinone. J. Antibiotics 33: 1331 1340, 1980

2) Yoshimoto, A.; Y. Matsuzawa, T. Oki, H. Naganawa, T. Takeuchi \& H. Umezawa: Microbial conversion of $\varepsilon$-pyrromycinone and $\varepsilon$-isorhodomycinone to 1-hydroxy-13-dihydrodaunomycin and $\mathrm{N}$ formyl-1-hydroxy-13-dihydrodaunomycin and their bioactivities. J. Antibiotics 33: 1150 1157, 1980

3) Yoshimoto, A.; T. OKi \& H. Umezawa: Biosynthesis of daunomycinone from aklavinone and $\hat{\varepsilon}$-rhodomycinone. J. Antibiotics 33: 1199 1201, 1980

4) Smith, T. H.; A. N. Fujlwara \& D. W. Henry: Adriamycin analogues. 2. Synthesis of 13-deoxyanthracyclines. J. Med. Chem. 21: 280 283, 1978

5) Matsuzawa, Y.; A. Yoshimoto, K. Kouno \& T. OKI: Baumycin analogs isolated from Actinomadura sp. J. Antibiotics 34: 774 776, 1981

6) Blumauerova, M.; E. Kralovcova, E. Hostalek \& Z. Vanek: Intra- and interspecific cosynthetic activity of mutants of Streptomyces coeruleorubidus and Streptomyces galilaeus impaired in the biosynthesis of anthracyclines. Folia Microbiol. 24: 128 135, 1979

7) Yoshimoto, A.; T. OKI, T. TAKeuchi \& H. Umezawa: Microbial conversion of anthracyclinones to daunomycin by blocked mutants of Streptomyces coeruleorubidus. J. Antibiotics 33: 1158 1166, 1980

8) Casay, M. L.; R. C. Paulick \& H. W. Whitlock: Carbon-13 nuclear magnetic resonance study of the biosynthesis of daunomycin and islandicin. J. Org. Chem. 43: 1627 1634, 1978

9) Fujiwara, A.; T. Hoshino, M. TAzoe \& M. Fujiwara: Auramycins and sulfurmycins, new anthracycline antibiotics: Characterization of aglycones, auramycinone and sulfurmycinone. J. Antibiotics 34: $608 \sim 610,1981$

10) Soga, K.; H. Furusho, S. Mori \& T. OKI: New antitumor antibiotics: 13-Methylaclacinomycin A and its derivatives. J. Antibiotics 34: 770 773, 1981

11) Komiyama, T.; Y. Matsuzawa, T. Oki, T. InUj, Y. Takahashi, H. Naganawa, T. Takeuchi \& H. UmeZAWA: Baumycins, new antitumor antibiotics related to daunomycin. J. Antibiotics 30: 619 621, 1977 